\section{Thatcher's government}

\section{The British Conservative Government is almost certain to be reelected but should change.}

A FEW days from now, Mrs Margaret Thatcher, British Prime Minister for the past four years, will have returned to Downing Street and will probably be too busy to remember the curious general election campaign that has occupied the British for the past month. It is, however, less certain that her ministerial colleagues will slip back as easily into their old routines. Some will no doubt have lost their parliamentary seats in the election today ( 9 June). Others will have been posted elsewhere in the government, while still others will have lost their jobs altogether, condemned (for the time being) to the life of an ordinary parliamentarian with no black limousine in attendance. That is a fate that many in the previous government deserve.

The reasons for the return of the Conservative Government, earlier this week apparently a foregone conclusion, will be endlessly debated, but the fact of it is remarkable. With more than three million people now unemployed, with industrial production no greater than fifteen years ago and with all kinds of social institutions (universities for example) fearful for their future, the government's electoral chances should have been slim. Moreover, unlike the other parties competing in the past few weeks for votes, the government has made no promises of improvement. More of the same has been offered as a recipe for the next four or five years. In at least three respects where the scientific community is concerned, however, the recipe needs radically to be changed.

\section{Management}

First, the administration of public support for the research enterprise needs to be overhauled. During its previous spell in office, the British Government resisted the argument (from the House of Lords Select Committee on Science and Technology) that there should be some means by which government expenditure on research and development could be more effectively assessed and coordinated, perhaps by saddling a minister with part-time responsibility for the task. The proposal was turned down, ostensibly on the grounds that the Prime Minister, herself trained as a chemist, was well placed to carry out that task, but more probably because powerful government departments believed the present chaos (also called plurality) more congenial. The results, however, have not been creditable. Little has been done to repair the breakdown of the dual-support system by means of which university research is supported, defence research remains virtually a law unto itself, while government policy has been driven by the fashionable preoccupations of some of its ministers - the widespread conviction that the universities are effete and, contradictorily, excesses such as the love affair with what is called information technology.

The flaw in the present arrangements, more obvious when the pattern of public support for research and development has been changing fast, is that there is no mechanism by which innovations can be intelligently discussed, and their consequences guessed at. The result is that when an influential cry goes up for more of this or less of that, every government agency does the same thing. The remedy is simple - to separate the research councils from education, to replace the Advisory Council on Applied Research and Development (a topic-oriented body) by a mechanism for reviewing the work of all the public agencies in research and development, and to ensure that they know individually what they are for. A part-time minister should indeed be put in charge.

Second, government administration of higher education should be made more responsible. The universities appear to have survived the budget reductions of the past two years, not always deservedly. But they are still unclear what the future holds for them. When and how the University Grants Committee will lift the invidious quota system which at present prevents universities from competing among themselves for students, and thus in efficiency, remains to be decided. Meanwhile, perhaps only temporarily, the gulf between the university system and the poly- technics has if anything been widened.

For several years, the overriding difficulty in these arrangements has been the fitfulness of government policy. Budgets have been cut and then partially restored. Even imaginative administrative innovations (such as the scheme for running a handful of universities on cash budgets and a loose rein - see Nature 26 May, p.270) have been canvassed in a way that unsettles the generality of the government's dependants. Nobody should object to change, but hasty unplanned change serves no purpose. Mrs Thatcher's new government needs somebody in charge whose policies will be more steadfast

School education is a still more formidable problem, largely because the government does not appreciate what it consists of. Irrelevantly, the previous government was much concerned with schemes for broadening parents' choice of which secondary schools their children should attend. Rightly, it was concerned with the improvement of "standards" in secondary education. Wrongly, it has not grappled with the central flaw in British secondary education that students, especially the most able, are educationally crippled by the narrow curriculum they must follow on the way to higher education. The government's election manifesto boasts of steps already taken to augment technical education in secondary schools. How many of those who profit will be able to speak some language other than English? Nobody objects to what the manifesto calls the pursuit of excellence in the schools, but so far it has been conducted too narrowly.

Third is the long-standing British problem, the economy. The government has insisted throughout the general election campaign that it cannot properly have a direct role in industrial innovation but that its task is merely to create the social and economic circumstances in which new enterprises can flourish. The principle is impeccable, but has not been followed in the past four years and may not be in the next five. In spite of having committed $£ 2,000$ million during this year to the training of young people who would otherwise be out of work, the British Government is spending less on vocational training than its industrial competitors (according to a document by the National Economic Development Office leaked to the Labour Party early in the election campaign). Fees paid by individuals to educational institutions must still come from taxed income. Spending on research and development is substantial when measured as a percentage of national income, but the gross domestic product is growing only slowly, while the absence of a mechanism for making research policy coherent means that much of what is spent is irrelevant to the government's declared purpose of encouraging innovation. Meanwhile, for reasons which are politically understandable but economically nonsensical, the government has continued to subsidize loss-making nationalized industries while preventing (in the interests of not borrowing the money) profitable state industries from becoming more efficient by the investment of sufficient capital. And the government's declared belief in competition as a spur to efficiency is belied by its attempt (cut short by the election) to sell off the country's chief telecommunications network (now nationalized) with entirely inadequate restrictions of its monopoly power.

\section{Economy}

Nobody pretends that the British economic climate can be changed by the Department of Industry acting on its own, but it is the only government department with a remit to intervene directly in industrial affairs. While its behaviour in the past four years has been in many ways consistent with what the government has been saying, the department has been too much constrained by timidity from using its spending power to make nationalized industries efficient and has also been the chief source of untrustworthy fashion, that for information technology in particular. A few months from now, the promise in the government's manifesto that its plan to sanction new cable television networks will be a substantial contribution to the emergence of new technology will seem ridiculous. The trouble seems to be that the government cannot easily tell how its principles should be applied in practice. It needs a clarity of purpose that it has so far lacked. 